DOI: 10.19195/0137-1150.168.29

Data przesłania artykułu: 22.09.2017

Data akceptacji artykułu: 5.12.2017

ANNA MARIA SKIBSKA

Uniwersytet im. Adama Mickiewicza w Poznaniu, Polska

\title{
Między roszadą a niebytem. Milana Kundery wadzenie się ze śmiercią
}

\author{
Tęsknota za Rajem jest tęsknotą człowieka do tego, \\ by nie być człowiekiem. \\ Milan Kundera ${ }^{1}$ \\ Zostaliśmy stworzeni, żeby żyć w raju. \\ Przeznaczeniemraju było nam służyć. \\ Nasze przeznaczenie zostało zmienione, \\ ale czy wraz z naszym przeznaczeniem \\ uległo także zmianie przeznaczenie raju, \\ oznajmione nie będzie.
}

Franz Kafka ${ }^{2}$

\section{Exordium, czyli o funeralnej strukturze pisma}

Potrzeba pisania o śmierci implikuje konieczność rozważenia sygnatury jako manifestacji nieobecności wszelkich podmiotowych doświadczeń przełożonych na język tekstowej tematyzacji. Innymi słowy, pisanie rodzi się w świetle melancholicznej utraty bezpośredniego przeżywania egzystencji i przyjmuje kształt swego rodzaju całunu, jaki spowija bezpowrotnie mijającą przeszłość. Owa elegijna forma całunu, podszyta apokaliptyczną frazą „,w proch się obrócisz”, pojawia się w Szibbolecie dla Paula Celana, w którym poezja buduje strukturę oporu względem doświadczenia jednostkowej skończoności czasu, chroniąc się w dacie (dacie

${ }^{1}$ M. Kundera, Nieznośna lekkość bytu, przeł. A. Holland, Warszawa 1996, s. 221.

${ }^{2}$ F. Kafka, Aforyzmy z Zürau, przeł. A. Szlosarek, oprac. R. Calasso, Kraków 2007, s. 95. 
związanej z powstawaniem każdej pojedynczej sygnatury poetyckiej). W efekcie twórca $O$ gramatologii pisze o szaleństwie dat, w których zawsze jest coś do przeczytania. Nawet jeśli tym czymś okazuje się nieczytelność wciąż odchodzącego, z każdym znakiem umierającego tekstu ${ }^{3}$. Przypomnieć muszę tu słowa myśliciela walczącego z natrętną metafizyką obecności przy użyciu poręczności odkrywanej przez Dasein w aktualnie interesującym mnie kontekście określanego jako „bycie-ku-śmierci”. Heidegger definiuje śmierć jako „możliwość niemożliwości” determinującą w sposób indywidualny horyzont egzystencjalny każdego jestestwa:

Bycie ku możliwości jako bycie ku śmierci winno się jednakże tak odnosić do śmierci, by odsłaniała się w tym byciu i dla niego jako możliwość. Takie bycie ku możliwości ujmujemy terminologicznie jako wybieganie (Vorlaufen) w możliwość. [...] Najbliższa bliskość bycia ku śmierci jako możliwość jest temu, co rzeczywiste, tak daleka jak to tylko możliwe. [...] Śmierć jako możliwość nie daje jestestwu nic „do urzeczywistnienia” ani nic, czym ono samo jako rzeczywiste mogłoby być. Jest ona możliwością niemożliwości wszelkiego odnoszenia się do [...], wszelkiego egzystowania ${ }^{4}$.

Na gruncie dekonstrukcji czerpiącej z destrukcji Heideggera formuła śmierci poddana zostaje znaczącej inwersji, w której wyniku staje się nie tyle „możliwością niemożliwości”, ile „niemożliwością możliwości”, jej jednorazowym i nieodwołalnym kresem, redukcją do materii w słowniku francuskiej psychoanalizy określanej mianem le corps morcelé ${ }^{5}$. „Niemożliwość możliwości” — to zmiana stanu skupienia materii, która po śmierci nie może już dłużej być człowiekiem (żyje na poziomie subatomowym, który zna rozpad pojmowany poza kategorią indywidualnej agonii). W kontekście pisma oraz pisania zadaniem wartym osobnego rozważenia wydaje się oryginalna propozycja autora Bycia $i$ czasu, czyli „możliwość niemożliwości” właśnie. Funeralność wszelkiego rodzaju sygnatur wynika z faktu, że zabezpieczają one nieobecność, wychylają się ku śmierci niejako wspak, à rebour, zahaczając o przeszłość będącą skupiskiem popiołów, śladów naszej minionej już egzystencji stawiających nader kruche podwaliny pod indy-

3 „Jeśli mówię, że sens daty ujawnia szaleństwo, pewien rodzaj Wahnsinn, to nie po to, aby wywołać jakieś emocje, ale tylko po to, aby powiedzieć, że w dacie, w przenikaniu, w przypadku każdej lektury istnieje coś do przeczytania [wyr. - A. M. S.]. [...] Szaleństwo drzemie w tym niepewnym spotkaniu, w tym przypadku heterogeniczności, który zaczyna nadawać sens i datować", J. Derrida, Szibbolet dla Paula Celana, przeł. A. Dziadek, Bytom 2000, s. 44.

${ }^{4}$ M. Heidegger, Bycie i czas, przekł., przedm. i przyp. B. Baran, Warszawa 2008, s. 330-331.

5 „Ciało pokawałkowane” stanowi stadium uprzednie względem iluzji podmiotowego ego, które za sprawą swego lustrzanego odbicia doświadcza unifikacji z własną somą, wcześnie postrzeganą jako zespół niezwiązanych z sobą członków; jest także projekcją śmierci, jej wyobrażeniową antycypacją symbolizowaną przez fantazmat korporalnego rozpadu czy dezintegracji: „The fragmented body manifests itself regularly in dreams when the movement of the analysis encounters a certain level of aggressive disintegration in the individual. It then appears in the form of disjointed limbs, or of those organs, represented in exoscopy, growing wings and taking up arms for intestinal persecutions - the very same that the visionary Hieronymous Bosh has fixed for all time in painting", J. Lacan, Ecrits, przeł. A. Sheridan, London 1977, s. 5. Zob. też B. Benvenuto, R. Kennedy, 'The Mirror Stage' (1936), [w:] iidem, The Works of Jacques Lacan. An Introduction, London 1986, s. 47-62. 
widualne archiwa, w których z czasem zaciera się konstytutywna dla jestestwa idiomatyczność. Niemniej owo paradoksalne „bycie-ku-śmierci” wspak, w planie egzystencji niemożliwe, staje się możliwością literatury, która bezustannie przesuwając własne granice, informuje nie tylko o właściwej sobie autotransgresji, lecz także oznajmia swoją spektralność - w jej cieniu rozmowa $z$ duchami bywa możliwa $^{6}$. Inny filozof, podobnie jak Heidegger będący niepokornym uczniem Husserla, pisze o śmierci jako o doświadczeniu radykalnej Inności, przy czym radykalność tę proponuje rozważać w zgodzie z ,fenomenologią-ponad-światłami”, w ramach której jawi się absolutną niepoznawalnością kwestionującą dodatkowo wszelkie epistemologiczne wysiłki podejmowane przez zafrasowane swoim byciem ratio. Emmanuel Lévinas, gdyż o nim tu mowa, projekt swojej słynnej fenomenologii włącza w ekspozycję konsekwentnie rozwijanej postawy wrogiej temu, co Jacques Derrida w Przemocy i metafizyce nazywa heliopolityką ${ }^{7}$. Przywołuję autora Imion własnych ze względu na oryginalne zagadnienie ekscendencji, która urzeczywistnia się w taktyce egzystencjalnej jednej z najważniejszych bohaterek Kundery, Agnes z Nieśmiertelności, taktyce omawianej w kolejnych pasażach tego tekstu. Obecność Lévinasa tłumaczy także poniższy passus wywiedziony z jego słynnego eseju poświęconego między innymi nieskończoności:

Nie wiadomo, kiedy nadejdzie śmierć. I co właściwie nadejdzie? Czym śmierć mi grozi? Nicością czy nowym początkiem? Nie wiem. Istota ostatniej chwili polega właśnie na niemożności poznania tego, co będzie, kiedy umrę. Absolutnie nie mogę uchwycić chwili śmierci — „nie leżącej w naszym zasięgu”, jak powiedziałby Montaigne. Ultima latet — w przeciwieństwie do wszystkich chwil mojego życia, które rozpościerają się między moimi narodzinami i moją śmiercią, i które mogę sobie przypomnieć lub antycypować. Śmierć przychodzi do mnie z chwili, nad którą w żaden sposób nie mogę zapanować. Nie zderzam się z przeszkodą, której w tym zderzeniu przynajmniej dotykam i przezwyciężając ją lub znosząc, włączam do swojego życia, a jej inność zawieszam. Śmierć jest zagrożeniem zbliżającym się do mnie jako tajemnica; określa ją jej sekret — zbliża się tak, że nie mogę jej przygarnąć, wziąć na siebie (assumer), tak, że czas, który mnie od niej dzieli, jednocześnie kurczy się i nie ustaje w tym kurczeniu, jakby zawierał ostateczny odstęp, którego moja świadomość nie może przekroczyć i przez który śmierć w pewien sposób do mnie przeskoczy. Ostatni odcinek drogi zostanie przebyty beze mnie, czas śmierci płynie pod prąd, Ja w swoim ku

${ }^{6}$ Konstytutywnym zdarzeniem owej rozmowy jest słynna scena z Hamleta, w której tytułowy bohater wchodzi $\mathrm{w}$ istotny dla dalszego przebiegu akcji dramatu dialog $\mathrm{z}$ duchem swojego nieżyjącego ojca. Istotę tego ducha w intrygujący sposób (i w porozumieniu z Freudem) objaśnia Marjorie Garber, pisząc te oto słowa: „And what is a ghost? It is a memory trace. It is the sign of something missing, something undone. It is itself At once a question, and the sign of putting things in question", M. Garber, Shakespeare's Ghost Writers. Literature as Uncanny Casuality, New York-London 2010, s. 173. O tym, że Szekspir nieodmiennie organizuje centrum kanonu literatury europejskiej, pisze zaś Harold Bloom w Shakespeare, center of the canon, [w:] idem, The Western Canon: The Books and School of the Ages, New York 1995, s. 45-75.

${ }^{7}$ Wywiedziona z platońskiej iluminacji heliopolityka ustanawia świat światła oraz jedności, doskonały i niezmienny, nieskażony doświadczeniem czasu. J. Derrida, Writing and Difference, przekł., przedm. i objaśn. A. Bass, London-New York 2010, s. 111. 
przyszłości będzie zatrzymane przez niepowstrzymany ruch z naprzeciwka, przez czyste zagrożenie płynące do mnie $\mathrm{z}$ absolutnej inności ${ }^{8}$.

\section{Strategia roszady}

François Ricard w swojej próbie sportretowania postaci zamieszkującej powieściowe światy Kundery zauważa rzecz istotną wynikającą z postaci tej umowności: jej egzystencja jest wprawdzie zarysowana (najczęściej poprzez wypiętrzenie węzłowych dla danego bohatera czy bohaterki doświadczeń), ale brak w tym obrazie szczegółów, z jakimi oswojony bywa czytelnik, powiedzmy, Balzaka. Postać u Kundery zachowuje swego rodzaju anonimowość, ażurowość czy przezroczystość: znany jest jej wiek, płeć, wykonywany zawód, ogólna sytuacja egzystencjalna zdeterminowana serią określonych zdarzeń. Przypomina nieco personę ze średniowiecznego moralitetu, której jednostkowa osobowość czy też pojedyncza niepowtarzalność ujęta jest w nawias, niejako wymazana czy też zawieszona. Niewiele wiemy także o jej zewnętrznej, somatycznej prezencji: pisarz unika przedstawiania fizycznych atrybutów kształtujących estetyczny wizerunek postaci, rezygnuje też z deskrypcji najbliższego jej otoczenia, zarówno intymnego, prywatnego, jak i publicznego. Ricard zauważa, pozostając, jak sądzę, w zgodzie z intencją Kundery, iż

Stripped of everything picturesque that would differentiate him, defined primarily by what might be called his basic existential marks- the very ones that make up the "figure" each character can then be seen as one of the multiple possibilities, one of the variations of that single figure thus made new and kept ever familiar ${ }^{9}$.

Zredukowana do wariacji lub możliwości postać ta może być interpretowana jako osobliwa, zaprojektowana wszak przez pisarza realizacja „miejsca niedookreślenia", w konfrontacji z którym władzę nad tekstem przejmuje, jak pisał przed laty Roman Ingarden, wyobraźnia czytelnika ${ }^{10}$. Schematyczność postaci pozwala przywołać centralną figurę retorycznej detrakcji, czyli elipsę, z którą w sposób szczególny związana jest Agnes z Nieśmiertelności. Aktywność elipsy przejawia się nie tylko w konstrukcji postaci, zarządza ona także kompozycją eseistycznych powieści Kundery stanowiących konkatenację epizodów odpowie-

${ }^{8}$ E. Lévinas, Całość i nieskończoność. Esej o zewnętrzności, przeł. M. Kowalska, Warszawa 2002 , s. 282-283.

9 „Odarty z całej swojej malowniczości, która mogłaby go wyróżniać, zasadniczo określony przez podstawowe właściwości, jakie można by nazwać jego elementarnymi cechami egzystencjalnymi — tymi, które czynią zeń po prostu postać — każdy bohater [u Kundery — A. M. S.] może być $\mathrm{w}$ efekcie postrzegany jako jedna $\mathrm{z}$ wielu możliwości, jedna $\mathrm{z}$ wariacji na temat pojedynczej osoby wciąż odnawianej i zapoznawanej, oswajanej bez końca", F. Ricard, Agnès's Final Afternoon. An essay on the work of Milan Kundera, przeł. A. Asher, London 2003, s. 75, przekład fragmentu własny.

${ }^{10}$ Zaangażowanie czytelnika nazwane zostaje konkretyzacją, która umożliwia transformację dzieła sztuki jako przedmiotu artystycznego w przedmiot estetyczny. R. Ingarden, O poznawaniu dzieła literackiego, przeł. D. Gierulanka, Warszawa 1976, s. 397-398. 
dzialnych za fenomen, który Marek Bieńczyk nazywa „pięknem eliptycznym” właśnie ${ }^{11}$. W analizowanym pisarstwie elipsa skojarzona jest często z rzeczniczką negacji, czyli ironią: tę figuratywną fuzję wykorzystywać także muszę w niniejszym tekście próbującym opowiedzieć o śmierci w kontekście Nieśmiertelności.

Roszada jest wymyślonym na początku XVII wieku ruchem szachowym polegającym na przesunięciu króla o dwa pola w kierunku wieży, a następnie ustawieniu wieży na polu, które minął król. Oparty na substytucji manewr ma na celu obronę króla, przedłużenie jego trwania, które w przestrzeni szachowej rozgrywki przedłuża trwanie jej samej. Dla Agnes urok roszady mieści się jednak w czym innym, mianowicie w zniknięciu króla, uczynieniu go niewidocznym i w optyce zakusów przeciwnika nietykalnym. Przeciwnikiem tym, warto rzecz dopowiedzieć, jest z perspektywy bohaterki świat ludzkiej cywilizacji. Strategia roszady stanowi w powieści miejsce, w którym pojawia się ojciec Agnes:

Gdy była mała, ojciec nauczył ją grać w szachy. Jedno z szachowych posunięć urzekło Agnes: posunięcie, które specjaliści nazywają roszadą: gracz przesuwa dwie figury naraz: wieżę stawia na polu obok króla, a króla przesuwa na pole za wieżę. Ten manewr bardzo jej się spodobał: nieprzyjaciel zbiera wszystkie siły, by zaatakować króla, i nagle król znika mu sprzed oczu: wyprowadza się. Agnes przez całe życie marzyła o takim posunięciu i w miarę jak jej zmęczenie rosło, marzyła o nim coraz silniej ${ }^{12}$.

Życie eliptycznej bohaterki toczy się pod wpływem dwóch zjawisk, ekstensji oraz ekscendencji. Ekstensja wiąże się z jej nieżyjącym od pięciu lat ojcem, a ściślej: z pragnieniem urzeczywistnienia jego wyborów, powtórzenia jego decyzji prowadzącym w sposób nieunikniony do kresu jej egzystencji (w planie fabuły rozstrzygniętym sceną wypadku samochodowego, w którym Agnes ginie). Aby zrozumieć marzenie bohaterki dotyczące ekscendencji, czyli wyjścia z własnego bycia, należy przyjrzeć się ojcu zamkniętemu w jej wspomnieniach, których kompulsywne przywoływanie utrzymuje w mocy pracę żałoby i stymuluje doświadczenie utraty odpowiedzialnej za melancholię Agnes. Ojciec bohaterki stanowi zaprzeczenie figury prawa opracowanej przez kanoniczną psychoanalizę, nie ma w sobie surowości super ego wyrażającej się pod postacią nieskończonego ciągu oczekiwań wobec swojego potomstwa, oczekiwań, które Franza Kafkę pchnęły swego czasu do napisania długiego i ironicznego listu do „najdroższego” rodzica ${ }^{13}$. Przypomina raczej ojca znikającego, pomniejszającego wagę swojego bycia, jakiego znamy z opowiadań Brunona Schulza ${ }^{14}$. Wiemy o nim tylko tyle,

${ }^{11}$ M. Bieńczyk, Książka twarzy, Warszawa 2012, s. 413. Więcej o tym zjawisku piszę w: Próby z Kundery. Kilka uwag na temat figuratywności, ,Slavia Occidentalis” 71, 2014, nr 2, s. 145-162.

12 M. Kundera, Nieśmiertelność, przeł. M. Bieńczyk, Warszawa 1995, s. 225.

13 Zob. F. Kafka, Dearest Father, przeł. H. i R. Stokes, Richmond 2010. W tym rozległym liście autor opisuje przeróżne sposoby radzenia sobie z przemożną władzą ojca oraz wszelkimi jego co do syna niespełnionymi oczekiwaniami.

${ }^{14} \mathrm{~W}$ tanatycznym kontekście mam tu przede wszystkim na myśli opowiadanie zatytułowane Ostatnia ucieczka ojca, w całości dedykowane stopniowemu odchodzeniu bohatera, który w dodatku na podobieństwo Gregora Samsy z Kafkowskiej Metamorfozy, zanim zniknie, prze- 
że jest nauczycielem akademickim, małomównym samotnikiem, miłośnikiem poezji sprawiającej, że „chwila bytu staje się niezapomniana i godna nieukojonej tęsknoty" "15. Samotność będąca niewątpliwie właściwością dystynktywną tego bohatera, konsekwentnie naśladowana przez Agnes, wyraża się między innymi odczuciem braku więzi z innymi ludźmi, braku zwalniającego z przeżywania emocji przez ludzkie gesty prowokowanych. Agnes pracuje nad szlifowaniem podobnej wobec świata postawy. Widać to szczególnie dobrze w jednej z inicjalnych scen Nieśmiertelności, w której bohaterka próbuje odciąć się od ulicznego zgiełku gestem zasłonięcia sobie uszu:

Idący z przeciwnej strony przechodzień rzucił jej nienawistne spojrzenie i popukał się w czoło... [...] Szła swoją drogą nie potrafiąc wyrzucić mężczyzny z myśli: choć osaczał ich ten sam hałas, uznał za konieczne pokazanie jej, że nie ma ona żadnego powodu, by zatykać sobie uszy, a może nawet żadnego do tego prawa. Mężczyzna przywołał ją do porządku naruszonego przez jej gest. W jego osobie nagany udzieliła jej równość, która nie uznaje, by ktoś nie godził się znosić tego, co muszą znosić wszyscy. To równość w jego osobie zakazała Agnes niezgody ze światem, w którym wszyscy żyjemy ${ }^{16}$.

Ewokowane przywołanym zdarzeniem refleksje wiodą Agnes do rozważań na temat nienawiści, od której wolny wydawał się jej ojciec — wolność ta jawi się jako potwierdzenie zaniku związków ze społeczeństwem jednoznacznie skazanym na dziedziczoną drogą płciową śmiertelną chorobę zwaną życiem; owo rozpoznanie tworzy dla zdarzenia jednostkowej śmierci nietuzinkową, zgoła paradoksalną perspektywę oznaczającą afirmację tego, co tworzy kwintesencję wspomnianej choroby. Będące zdarzenia tego konsekwencją samobójstwo bohaterki wynika z niechęci do fundowanych przez ludzką egzystencję pułapek, pośród których istotną funkcję pełni nienawiść właśnie:

Pułapką nienawiści jest to, że zbyt ściśle wiąże nas z przeciwnikiem. [...] Wspomnienie o ojcu zaczęło ją uwalniać od nienawiści, której się poddała przed chwilą. Zatruty obraz mężczyzny pukającego się w czoło powoli znikał z jej myśli i nagle wyłoniło się w nich zdanie: nie mogę ich nienawidzić, ponieważ nic mnie z nimi nie łączy; nie mamy ze sobą nic wspólnego ${ }^{17}$.

Równość, której pożąda pukający się w czoło mężczyzna, zostaje ostatecznie zniesiona „nieludzkim” zdarzeniem dobrowolnego rozstania się z życiem starannie wyreżyserowanym przez Kunderowską rzeczniczkę elipsy ${ }^{18}$.

mienia się w groteskowego skorupiaka: „Umierał [ojciec - A. M. S.] wielokrotnie, zawsze jeszcze nie doszczętnie, zawsze z pewnymi zastrzeżeniami, które zmuszały do rewizji tego faktu. Miało to swoją dobrą stronę. Rozdrabniając tak śmierć swą na raty, oswajał nas ojciec z faktem swego odejścia”, B. Schulz, Sklepy cynamonowe. Sanatorium pod klepsydra, Warszawa 1994, s. 313.

${ }^{15}$ M. Kundera, Nieśmiertelność..., s. 29.

16 Ibidem, s. 26-27.

${ }^{17}$ Ibidem, s. 27-28.

${ }^{18} \mathrm{Z}$ perspektywy fabuły śmierć Agnes wydaje się dziełem przypadku: próbując ominąć anonimową dziewczynę, która postanawia zakończyć życie, siadając na środku drogi, bohaterka gwałtownie zjeżdża na pobocze, w efekcie czego jej pojazd dachuje, a doznane przez Agnes 
Moduły powieści poświęcone narracji o dojrzewającej do totalnej ekscendencji Agnes są rekonstrukcją jej niełatwych relacji z młodszą siostrą, Laurą, oraz mężem, Paulem: postacie te są tak skonstruowane, aby tworzyły ironiczną kontradykcję wobec mistrzyni odejmowania ${ }^{19}$, strategii, która pozwala bohaterce dążyć do spełnienia pragnienia na temat „możliwości najbardziej własnej, bezwzględnej, nieprześcignionej niemożliwości" ${ }^{20}$. Realizację tego pragnienia poprzedza słynne popołudnie spędzone przez Agnes z dala od świata ludzi w przestrzeni alpejskiej przyrody, potwierdzające osiągnięcie nieledwie mistycznego doświadczenia „wymknięcia się wszystkim” zbieżnego z utratą tego, co w życiu najbardziej nieznośne, czyli „bycia własnym ja”. Na tle tego ocierającego się o epifanię zdarzenia dojrzewa w bohaterce przeświadczenie o radykalnej różnicy między życiem a byciem, spośród których pierwsze naznaczone jest bolesnym zniewoleniem przez obraz własnego ja, drugie zaś — z odzyskaniem swobody płynącym z radości czystej egzystencji, przedustawnej i niezdeterminowanej ludzkimi uwarunkowaniami bytowymi: „Żyć nie jest szczęściem. Żyć: nieść przez świat swoje bolesne ja. Ale być, być jest szczęściem. Być: przemienić się w nieckę, w kamienne naczynie, w które wszechświat spływa jak ciepły deszcz"21. Bycie okazuje się uwolnieniem od koniecznie funkcjonalnej, teleologicznej aktywności konstytuującej podmiotową samoświadomość jednoznacznie przyporządkowaną do toru własnej egzystencji. Jest ono w konsekwencji zgodą na osobliwą detronizację jednostkowego ,ja”, zgodą, której możliwość wiedzie przez apofatyczny próg nieistnienia: jego przekroczenie oznacza osiągnięcie ocalającej bierności, zabezpieczającej przed frustrującą niedoskonałością materii i niespełnieniem intencjonalnych pragnień duchowych.

obrażenia okazują się śmiertelne: umiera w pobliskim szpitalu tuż przed przybyciem jej męża Paula. Dokonując oględzin ciała żony, Paul odkrywa inną, nieznaną mu wcześniej twarz Agnes: „Kobieta w białym kitlu odchyliła prześcieradło. Zobaczył znajomą twarz, bladą i piękną, a jednak zupełnie inną: usta, choć wciąż spokojne, układały się w linię, jakiej nigdy nie znał. Nie rozumiał wyglądu tej twarzy. Nie umiał pochylić się nad nią i ją pocałować. [...] Patrzył na twarz o przymkniętych powiekach: ten dziwny uśmiech, którego nigdy nie widział, nie dla niego był przeznaczony; uśmiech ten przeznaczony był dla kogoś, kogo Paul nie znał, i mówił coś, czego Paul nie rozumiał", ibidem, s. 256.

${ }^{19}$ Powieściowa arytmetyka Kundery zakłada oba podstawowe działania, dodawanie (Laura) oraz odejmowanie (Agnes), służące podtrzymywaniu złudzenia na temat własnej niepowtarzalności: „Agnes odejmuje od swego ja to wszystko, co jest zewnętrzne i zapożyczone, aby w ten sposób zbliżyć się do swej czystej istoty (ryzykując, że w wyniku kolejnego odejmowania otrzyma zero). Metoda Laury jest dokładnie odwrotna: aby uwidocznić ją, ułatwić jego uchwycenie, aby zwiększyć jego objętość, nieustannie dodaje do niego nowe przymioty, z którymi próbuje się utożsamić (ryzykując, że pod sumą przymiotów utraci istotę ja)", ibidem, s. 98-99.

${ }^{20}$ M. Heidegger, Bycie i czas..., s. 316.

${ }^{21}$ M. Kundera, Nieśmiertelnosść..., s. 248. 


\section{Przezroczystość}

Rezygnacja z poszczególnych atrybutów oraz właściwości stanowiących mniej bądź bardziej niedogodne efekty oddziaływania kulturowych instytucji stoi u podstaw komentowanej wyżej chęci wyprowadzenia się ze świata (ewentualnie niepełnego, eliptycznego w nim uczestnictwa), które grawituje ku osiągnięciu stanu przezroczystości. W optyce marzenia o literaturze doskonałej Roland Barthes ów stan utożsamia z wycofaniem się w ciszę bądź z milczeniem, Agnes zaś jawi się spełnioną sugestią takiej właśnie projekcji. Marek Bieńczyk zauważa interesujący rys tej fascynacji:

Barthes mówił przy okazji Żywota Rancego to jeszcze: „W sumie literatura jest niczym innym jak odnogą, w której się gubimy; literatura rozdziela, odwodzi”. Barthes odkrywa u Chateaubrianda model (a może ideał) literatury dochodzącej do skraju milczenia, do zawieszenia siebie samej, literatury ażurowej, wybielającej ciężar własnych konstrukcji i zdań, lecz wciąż trwającej w swym ruchu zanikania, używającej z całą siłą języka w istocie zbędnego. Przezroczystość łączy się z imperatywem wyciszania, wybielania znaczeń; jest narastającym tłem, nieobecnością przechodzącą stopniowo w plan pierwszy ${ }^{22}$.

Pełny efekt przezroczystości osiągnięty przez Agnes osuwającą się w absolutną ciszę może być związany, choćby tylko na mocy akcydentalnego działania przypadku, z pragnieniem wypowiadanym przez pierwszoosobowego narratora Nieśmiertelności. W jednej z rozlicznych dyskusji prowadzonych z Avenariusem zauważa on rzecz następującą:

istotą powieści jest mówienie tego, co jedna powieść może powiedzieć... Ten, kto jest na tyle szalony, by pisać dzisiaj powieści, powinien jeśli chce zapewnić im ochronę, pisać tak, by nie dało się ich adaptować, innymi słowy, tak, by nie dało się ich opowiedzieć23.

W takiej sytuacji jedyną możliwą odpowiedzią na sygnaturę jest kontrsygnatura, potwierdzająca szeregiem konstruowanych pytań i spekulacji właśnie działanie owej przezroczystości. Jej milczenie, sygnowane niemożliwością czytania poza aporią interpretacji obwieszczającej niewłaściwość deszyfracji metafor od zawsze należących do sfery językowych aberracji, skojarzyć można także z dwoma innymi stanami opisywanymi w Nieznośnej lekkości bytu: zapomnieniem pożądanym przez Sabinę oraz schodzeniem na pobocze, które wciela w życie za przykładem Nietzschego Teresa. W Sztuce powieści Kundera pisze: „Sabina nie ma żadnego powodu, żeby ukrywać cokolwiek, tymczasem ulega irracjonalnemu pragnieniu, aby o niej zapomniano. Zapomnienie: najwyższa niesprawiedliwość i zarazem największe pocieszenie"24. Hołduje tej postawie także ojciec Agnes, który przed śmiercią czyni wszystko, aby zlikwidować najmniejsze nawet dowody swojego istnienia:

22 M. Bieńczyk, Przezroczystość, Warszawa 2015, s. 254.

${ }^{23}$ M. Kundera, Nieśmiertelność..., s. 229.

${ }^{24}$ M. Kundera, Sztuka powieści. Esej, wyd. drugie zmienione, przeł. M. Bieńczyk, Warszawa 2004, s. 132. 
W ostatnich latach życia ojciec stopniowo niszczył wszystko po sobie: nie pozostawił nawet ubrań w szafie, żadnego rękopisu, żadnych notatek z wykładów, żadnego listu. Zatarł po sobie wszystkie ślady i nikt tego nie dostrzegł. Raz tylko przez przypadek złapano go na niszczeniu zdjęć. Ale i tak podarł je wszystkie. Żadne się nie zachowało ${ }^{25}$.

Partykularne zaangażowanie $\mathrm{w}$ egzystencję, słabnące $\mathrm{z}$ każdą stronicą Nieznośnej lekkości bytu, w wypadku Teresy manifestuje się stopniowym odchodzeniem od człowieczeństwa, usadowieniem się na poboczu, w przestrzeni rozluźnionych relacji między światem a językiem przez ów świat bezustannie reifikowanym. Zrywając z iluzją komunikacji język także sprowadza swych użytkowników do poziomu rzeczy: wywłaszcza z indywidualnej niepowtarzalności, spycha w milczenie, któremu hołdują komentowane bohaterki Kundery. Sygnałem wspomnianych wyżej pękających więzi jest sen o złotych rogalikach indukowany umierającą suczką Karenin, sen wiodący ku refleksji na temat świadomości czasu i przemijania, świadomości owego „bycia-ku-śmierci”, od jakiej wolne ma być, zdaniem Kundery, zwierzę, pełnoprawny mieszkaniem Raju, którego nigdy nie był zmuszony opuścić ${ }^{26}$. Stanowisko to, podszyte zdecydowanie antropocentryczną jednak interpretacją, ewokuje nie tylko problem teologii zwierząt (lub szerzej: teologii bytów różnych od człowieka), ale propaguje, można by rzec, model literatury ekologicznej zainteresowanej peryferiami, inwestującej w temat otoczenia czy egzystencjalnego środowiska, które dobrze byłoby uwolnić od dominacji ludzi, owych „nihilistycznych myśli” tłoczących się w głowie Boga, żeby odwołać się do słynnego aforyzmu Franza Kafki ${ }^{27}$. W głośnej powieści Auto da fé Elias Canetti pisze między innymi o świecie bez głowy — choć powodowany odmienną intencją Kundera także miejscami sugeruje potrzebę pracy nad światem oswobodzonym spod niszczycielskiej władzy ego, co osobliwie zbliża go do drogi filozoficznej walki, po której stąpa myśl Lévinasa niestrudzenie wadząca się z ,egologią, 28 .

${ }^{25}$ M. Kundera, Nieśmiertelność..., s. 240.

$26,[$ Ż]aden człowiek nie może przynieść drugiemu człowiekowi daru idylli. To umie zrobić tylko zwierzę, ponieważ nie zostało wygnane z Raju", M. Kundera, Nieznośna lekkość bytu..., s. 222-223. „W konsekwencji bohaterka (Teresa) dąży do przeniesienia się w inny rejestr egzystencji, w którym każda potencjalna (zmuszająca zatem do ejdetycznych wątpliwości) interpretacja jej zachowań i intencji stanowiłaby nieprzeniknioną tajemnicę, uwalniającą od ułomnych właściwości cechujących ludzkość”, A. M. Skibska, Retoryka erotyzmu w prozie Milana Kundery, „Bohemistyka” 2016, nr 1, s. 36-37.

27 Por. J. Derrida, Edmond Jabès i pytania księgi, przeł. A. Wodnicki, „Literatura na Świecie" 2001, nr 7, s. 143.

28 Walka ta wkracza na grunt przede wszystkim etyczny, u Emmanuela Lévinasa pomyślany w zgodzie z judaistyczną heteronomią, w której „sobość” warunkowana jest odpowiedzialnością za współkonstytuującego ową „sobość” Innego: „Bycie uzyskiwałoby znaczenie dzięki relacji Jeden-za-drugiego, dzięki substytucji Toż-samego Innym”, E. Lévinas, Inaczej niż być lub ponad istota, przeł. P. Mrówczyński, Warszawa 2000, s. 48. 


\section{Spektralność albo o trwałości patriarchalnych założeń (także w kwestii powieści)}

Można by rozpocząć ten końcowy pasaż od wydarzenia zwanego zasadzką pamięci, która okazuje się residuum nawiedzenia odsyłającego do wspomnianej wcześniej rozmowy z duchami. W przypadku Agnes duchem tym jest jej ojciec inspirujący do naśladownictwa streszczającego się w ekstensji oraz ekscendencji. Będąc figurą odroczonego prawa (prawa, które się wycofuje) pozostaje jednak ojcem, centralnym punktem odniesienia modelującym egzystencję bohaterki, warunkującym jej zmierzającą do niebytu przyszłość. W podobnej sytuacji znajduje się Tamina z Księgi śmiechu i zapomnienia wtłoczona przez narrację w swego rodzaju uwięzienie w utraconym czasie organizowanym uprzednio przez jej zmarłego męża - w przeciwieństwie do Agnes nie pożąda własnej nieobecności w świecie bezwzględnie spisującym na straty tych, którzy nie znajdują w nim dostatecznego umocowania. Pozbawiona patriarchalnych instrukcji grawituje jednak Tamina w kierunku własnej śmierci kończącej jej fantasmagoryczny pobyt na groteskowej wyspie dzieci ${ }^{29}$. W wypadku obu bohaterek spektralność, której doświadczają, polega na poddańczej przynależności do „rzeczywistości” nieżyjących mężczyzn nawiedzających myśli Agnes oraz Taminy ${ }^{30}$. Niewoląca relacja $\mathrm{z}$ widmami doprowadza do tragicznej finalizacji ich losu, oznaczając pełną realizację popędu śmierci zagrażającego wszelkim zasadom i zawiadującego tym, co Derrida nazywa gorączką archiwum ${ }^{31}$. Jednakże właśnie ta par excellence spektralna instytucja funduje, na sposób osobliwie mesjański ${ }^{32}$, przyszłość, w tym

29 Życie Taminie odbiera żywioł — tonie, usiłując opuścić wyspę dzieci, co Kundera przedstawia, w taki oto sposób finalizując przedostatnią część powieści: „Czyżby pływała przez całą noc w tym samym miejscu? Opanowało ją przerażenie i w chwili, gdy straciła nadzieję, poczuła, że jej członki są słabe, a woda lodowata. Zamknęła oczy i starała się płynąć dalej. Nie wierzyła już, że dopłynie na drugą stronę: myślała tylko o swojej śmierci i pragnęła umrzeć gdzieś dalej w wodzie, bez obcych dotknięć, sama, jedynie z rybami”, M. Kundera, Księga śmiechu i zapomnienia, przeł. P. Godlewski, A. Jagodziński, Warszawa 1993, s. 193.

30 „Even women with whom we are expected to identify, like Tamina in Forgetting, like Agnes in Immortality, belong to men in molecules of their memory: Tamina to her dead husband, Agnes to her dead father", J. Leonard, Reading for My Life: Writings 1958-2008, wstęp E. L. Doctorov, red. S. Leonard, New York 2012, s. 129.

31 „Above all [...] beyond or within this simple limit called finiteness or finitude, there is no archive fever without this death drive, this aggression and destruction drive. [...] There is not one archive fever, one limit or one suffering of memory among others: enlisting the in-finite, archive fever verges on radical evil", J. Derrida, Archive Fever: A Freudian Impression, przeł. E. Prenowitz, Chicago-London 1996, s. 19-20.

32 Istotę tej mesjańskości (wyzutej z teologicznego kontekstu) określa właśnie fenomen rozmowy z widmem, o którym Derrida pisze tak: „Być może pytanie to należy sformułować inaczej: czy można się w ogóle zwrócić do kogoś lub czegoś, jeśli nie towarzyszy temu powrót jakiegoś widma? Jeśli ‘uczony' przyszłości, ‘intelektualista', kocha sprawiedliwość, powinien jej się uczyć i to właśnie od widma. Powinien uczyć się żyć, ucząc się nie tego, jak prowadzić konwersację, lecz tego, jak z nim — lub z nią — rozmawiać, jak pozwolić mu mówić lub jak oddać mu głos, nawet 
także literatury przez Kunderę postrzeganej przez pryzmat „wzgardzonego dziedzictwa Cervantesa" umożliwiającego rozmowę z duchami przednowoczesnego powieściopisarstwa ${ }^{33}$. Wiedzie do niej droga wymagająca kolejnej śmierci, tym razem symbolicznej, o czym poucza historia kresu wieku lirycznego opowiadana na kartach powieści Życie jest gdzie indziej, której narcystyczny (poetycko w sobie rozkochany) bohater Jaromil w planie fabuły „rzeczywiście” rozstaje się z życiem ${ }^{34}$.

Dokonując zawieszenia tego, co zwie się tradycyjnie konkluzją, stawić muszę czoła pytaniu o sens pisania o śmierci, skoro „nie jest doświadczeniem przeżytym, nie ma vivencia mojej śmierci" ${ }^{35}$. Być może, tematyzując kres bycia i pozwalając na nawiedzenie przez widma znane i anonimowe, przygotowujemy się do spotkania $\mathrm{z}$ tym, co niewyrażalne... Elegijna działalność pisania, zwrócona w stronę przeszłości (nieobecności), intonuje pieśń przyszłości, w której nasze własne istnienie rozpierzchnie się niebawem w przezroczystości.

\section{Bibliografia}

Benvenuto B., Kennedy R., The Works of Jacques Lacan. An Introduction, London 1986.

Bieńczyk M., Książka twarzy, Warszawa 2012.

Bieńczyk M., Przezroczystość, Warszawa 2015.

Bloom H., The Western Canon: The Books and School of the Ages, New York 1995.

Derrida J., Archive Fever: A Freudian Impression, przeł. E. Prenowitz, Chicago-London 1994.

Derrida J., Edmond Jabès i pytania księgi, przeł. A. Wodnicki, „Literatura na Świecie” 2001, nr 7.

Derrida J., Szibbolet dla Paula Celana, przeł. A. Dziadek, Bytom 2000.

Derrida J., Widma Marksa. Stan długu, praca żałoby i nowa Międzynarodówka, przeł. T. Załuski, Warszawa 2016.

Derrida J., Writing and Difference, przekł., przedm. i objaśn. A. Bass, London-New York 2010.

Garber M., Shakespeare's Ghost Writers. Literature as Uncanny Causality, New York-London 2010.

w samym sobie, w innym, jak oddać głos innemu w samym sobie: widma są bowiem zawsze tutaj, nawet jeśli nie istnieją, nawet jeśli już ich nie ma, nawet jeśli jeszcze ich nie ma", J. Derrida, Widma Marksa. Stan długu, praca żałoby i nowa Międzynarodówka, przeł. T. Załuski, Warszawa 2016, s. 278.

33 „Dle autora se každý romanopisec rodi na ruinach svého lyrického světa (lyrický věk je časem, v němž je člověk soustředěný výradně na sebe). Román jako Cervantesův vynález začina tam, kde autor rozthává oponu pre-interpretace. Každý text, který je jen oslavou konvenční pózy a opotžebovaných symbolu, se vylučuje z historie románu, jehož znakem je právě destruktivní gesto a ironie”, K. Hvížd’ala, Restaurováni slov (eseje a texty o médiích 2005-2008), Praha 2008, s. 148 .

${ }^{34}$ Ironiczna narracja zgotowuje mu śmierć zgoła niepoetycką, uwikłaną dodatkowo w czułostkową relację z matką (co rzuca kolejny snop światła na mizoginiczny charakter powieści Kundery), którą odzwierciedla projekcja pogrzebu „,prawdziwego” poety: „Już leży kamień nad trumną Rimbauda, ale jego mama, jak wiadomo, kazała sobie jeszcze otworzyć rodzinny charlevillski grobowiec. Widzicie ją, tę surową panią w czarnej sukni? Zagląda w ciemną, wilgotną czeluść i upewnia się, że trumna jest na swoim miejscu i że jest zamknięta. Tak, wszystko jest w porządku. Arthur leży i nie ucieka. Arthur już nigdy nie ucieknie. Wszystko jest w porządku”, M. Kundera, Życie jest gdzie indziej, przeł. J. Illg, Warszawa 2002, s. 255.

35 P. Ricoeur, Żyć aż do śmierci oraz fragmenty, przeł. A. Turczyn, Kraków 2008, s. 66. 
Heidegger M., Bycie i czas, przekł., przedm., przyp. B. Baran, Warszawa 2001.

Hvížd’ala K., Restaurování slov (eseje a texty o médiich 2005-2008), Praha 2008.

Ingarden R., O poznawaniu dzieła literackiego, przeł. D. Gierulanka, Warszawa 1976.

Kafka F., Aforyzmy z Zürau, przeł. A. Szlosarek, oprac. R. Calasso, Kraków 2007.

Kafka F., Dearest Father, przeł. H. i R. Stokes, Richmond 2010.

Kundera M., Księga śmiechu i zapomnienia, przeł. P. Godlewski, A. Jagodziński, Warszawa 1993.

Kundera M., Nieśmiertelność, przeł. M. Bieńczyk, Warszawa 1995.

Kundera M., Nieznośna lekkość bytu, przeł. A. Holland, Warszawa 1996.

Kundera M., Sztuka powieści. Esej, wyd. drugie zmienione, przeł. M. Bieńczyk, Warszawa 2004.

Kundera M., Tożsamość, przeł. M. Bieńczyk, Warszawa 2015.

Kundera M., Życie jest gdzie indziej, przeł. J. Illg, Warszawa 2002.

Lacan J., Ecrits, przeł. A. Sheridan, London 1977.

Leonard J., Reading for My Life: Writings 1958-2008, wstęp E. L. Doctorov, red. S. Leonard, New York 2012.

Lévinas E., Całość i nieskończoność. Esej o zewnętrzności, przeł. M. Kowalska, Warszawa 2002.

Lévinas E., Inaczej niż być lub ponad istota, przeł. P. Mrówczyński, Warszawa 2000.

Ricard F., Agnès's Final Afternoon. An essay on the work of Milan Kundera, przel. A. Asher, London 2003.

Ricoeur P., Żyć aż do śmierci oraz fragmenty, przeł. A. Turczyn, Kraków 2008.

Schulz B., Sklepy cynamonowe. Sanatorium pod klepsydra, Warszawa 1994.

Skibska A. M., Próby z Kundery. Kilka uwag na temat figuratywności, „Slavia Occidentalis” 71, 2014, $\mathrm{nr} 2$.

Skibska A. M., Retoryka erotyzmu w prozie Milana Kundery, „Bohemistyka” 2016, nr 1.

\section{Between a castling move and non-existence: Milan Kundera's self-quarreling death}

\section{Summary}

The article is initiated by an introductory assumption regarding the funeral structure of writing which, in the process of its self-constitution, always has to face the absence of its content being a subject of thematization. Maintaining the aforementioned assumption and referring to certain philosophical contexts (Heidegger, Lévinas, Derrida), the author tends to concentrate subsequently on Agnes, the elliptical character of Immortality, since she is perceived as an embodiment of being realized between a strategy of a castling move and a desire of non-existence. In order to accomplish this desire, Agnes conducts a peculiar game of subtraction, consisting in the gradual erasing of the traces of her own existence. The final event of splitting up with the world means, therefore, a definitive gesture of withdrawing from mankind with which Agnes cannot neither reconcile nor identify.

Keywords: being-to-death, ellipsis, castling move, extension, excedence, non-existence 


\section{Mezi rošádou a nebytim: Kunderovo hádání se smrti}

\section{Obsah}

Vstupním předpolkadem tohoto článku je existence funerální struktury pisma, které vzniká vždy za nepř́ítomnosti obsahu, jenž je předmětem tematizace. Pokud to př́ijmeme jako fakt a budeme na tento předpoklad aplikovat tanatické filozofické kontexty (Heidegger, Lévinas, Derrida), budeme se moci plně soustředit na eliptické hrdince Nesmrtelnosti, protože ztělesňuje existenci rozprostírajicí se mezi strategií šachové rošády a touhou po nebytí. Na cestě spějíci k realizaci této touhy Ahnes propadá hře spočívajicí v postupném zatracování vlastní existence. Závěrečné rozloučení Agnes se světem symbolizuje její konečné odmítnutí lidstva, se kterým se nedokáže vyrovnat nebo identifikovat. Směřováni hrdinky k nebyti je tedy literárním konstruktem, prostřednictvím kterého Kundera kriticky nahlíži na lidský druh a vynikajicim způsobem reviduje konvenčni pohledy na vlastnosti, které jsou lidem píipisovány.

Kličová slova: směřování ke smrti, elipsa, rošáda, extenze, excedence, nebyti 